\title{
Shadow Economy in Tourism: Some Conceptual Considerations from Croatia
}

\author{
Oliver Kesar* \\ Katarina Čuić
}

\begin{abstract}
Although the importance of tourism for the Croatian economy is widely recognized and well documented, the issues related to the existence of shadow economy in tourism are not yet fully investigated and resolved. In spite of many attempts to estimate the size and impacts of shadow economy in tourism, there is still much controversy regarding the scope of the research area and the appropriateness of methodological approaches used to quantify this complex phenomenon. The present study aimed to (1) summarize the existing body of empirical evidence related to the shadow economy in tourism, with special reference to the case of Croatia, and to (2) shed some more light on additional aspects and variables which have been found to be important determinants for better understanding of the nature of the shadow economy in tourism. In order to reduce the adverse impacts of the shadow economy in tourism, some policy recommendations are suggested.
\end{abstract}

Keywords: shadow economy; tourism; Croatia

JEL Classification: L83, O17, Z31

\section{Introduction}

For many countries tourism is an important source of income, employment, export earnings, public revenues and business opportunities. Therefore, it is not surprising that many governments recognize tourism as a set of powerful tools for attracting investments, enhancing public infrastructure, and increasing the standard of living for local communities in tourism destinations. These benefits are usually more noticeable and diverse in large tourism destinations and their communities, but they are also visible in small and remote tourism receiving areas where service providing

\footnotetext{
* Oliver Kesar is at the Faculty of Economics and Business Zagreb, University of Zagreb, Zagreb, Croatia.
} 
to temporary visitors is often the only source of economic benefits, such as small islands, mountain resorts, and various rural settings (i.e. national parks, cycling routes, wildlife-watching locations etc.). Due to diversity of its economic structure and high multiplier effects, an overall economic impact of tourism is not limited to the frontline businesses that provide services and sell products to tourists, but also involves many other tourism-supporting producers and service providers who create a multifaceted network of value-added chains according to their roles and interests in the market. Such complex and highly fragmented economic structure, in which service providing significantly prevails, triggers the emergence of the shadow economy, with all its positive and negative implications.

Taking its wider indirect and induced impacts into account, tourism has contributed US\$7.6 trillion to the global economy, US\$1.4 trillion to the world exports and supported 292 million jobs in 2016. This was equal to $10.2 \%$ of the world's GDP, $6.6 \%$ of total world exports (almost $30 \%$ of total world services exports) and approximately 1 in 10 of all jobs (WTTC, 2017a). According to the UNWTO (2017) global tourism statistical record for 2016, international tourism has reached a peak of over 1.2 billion international tourist arrivals and over US\$1.2 trillion of international tourism receipts, while domestic tourism was estimated to contribute global tourism movements with additional five to six billion travellers. In the same year, Europe held traditionally the largest shares in world's total number of international tourist arrivals and international tourism receipts, of $49.9 \%$ (616.2 million) and 36.7\% (US\$447.3 billion), respectively, followed by Asia and the Pacific (of $25.0 \%$ and 30.1\%), Americas (of 16.1\% and 25.7\%), Middle East (of 4.3\% and 4.7\%), and Africa (of 4.7\% and 2.9\%). Despite the maturity of the regional market and slight decrease in global tourism market shares, Europe still remains the most important tourist generating and tourism receiving region of the world, whose international tourism was growing by $2.8 \%$ annually during the $2005-2016$ period, while estimates until 2030 indicate a steady growth of $1.8 \%$ per year (UNWTO, 2017).

As a Mediterranean country, Croatia enjoys large economic benefits from seaside tourism development. Despite significant efforts to develop inland tourism product, seaside tourism in Croatia still generates approximately $87 \%$ of total tourist arrivals and $95 \%$ of total overnight stays (CBS, 2017a). According to the national statistical database, in 2016, Croatia has recorded in total 16.1 million tourist arrivals and 88 million tourist overnight stays in all types of tourist accommodation facilities, in which foreign overnight stays hold a significant share of nearly $88 \%$ (CBS, 2017b; CBS, 2017c). In the same year, inbound tourism in Croatia has generated more than US\$9.6 billion of international tourism receipts, while tourism led export was contributing with $70.5 \%$ in total export of services and $38.1 \%$ in overall exports (CNB, 2017). According to the WTTC assessment, in 2016, tourism in Croatia directly has contributed to the national GDP with $10.7 \%$, while total contribution to GDP was estimated at $24.7 \%$ (WTTC, 2017b). Prior to that report, Croatia's third edition of Tour- 
ism Satellite Account, using 2011 data, has revealed that direct economic impact of tourism was estimated at $10.4 \%$ of the national GDP, while total economic impact of tourism (direct and indirect) was estimated at 14.3\% (Ivandić et al., 2014). Bearing in mind that these two reports are based on 2016 and 2011 data, respectively, a significant difference in relative values (component shares) is seen only in the calculation of indirect economic effects of tourism. Thus, the comparable sizes of direct economic impacts of tourism in both reports give us the right to consider some values in these two reports comparable to a certain extent. Considering the significant difference in calculated values of total economic impact of tourism on Croatia's GDP, it can be concluded that domestic report has omitted to calculate at least two categories: 1) induced economic impacts, and 2) the value of the shadow economy generated by tourism-related economic activities. Such discrepancy was also one of the reasons to undertake the present study.

On account of previously mentioned facts and figures, which clearly indicate the size and economic importance of tourism, particularly in Europe and Croatia, the prevalence of the shadow economy in tourism might have serious implications for the market stability and the well-being of the host communities in tourism destinations. For these reasons, shadow economy in tourism is constantly under the spotlight of tax authorities, academics, and market competitors, who still use scarce methodology and limited data to monitor its size and excessive negative impacts.

Therefore, the purpose of the present study is to summarize findings from the previous studies and shed some more light on the issues related to the occurrence of shadow economy in Croatia's tourism, having in mind that Croatia is the fourth most tourism-intense country in Europe, after Malta, Iceland and Montenegro, measured by nights spent by residents and non-residents at tourist accommodation establishments per inhabitant (Eurostat, 2017).

\section{The Shadow Economy: Theoretical and Empirical Background}

\section{Definition and Conceptual Framework of the Shadow Economy}

The shadow economy exists in all countries in the world. As a result, every country appears to have dual economies - an official economy and a shadow economy (Tan et al., 2016). In seeking to understand the size of the world economy, Fleming et al. (2000) argue that we are usually guided by official statistics on output, trade and investment, but omit to quantify the size of shadow economy due to complex methodology, scarce statistical data and much of controversies in its definition. To date, there is no consensus on the definition of shadow economy (Feige, 1990; Bajada, 1999; Caridi \& Passerini, 2001). Since the term 'shadow economy' comprises various economic activities, contrasting them from doubtfully legal to completely illegal 
(see Table 1), it is difficult to provide formal definition. In most cases, the definitions and concepts of the shadow economy depend on the chosen estimation methods and measurements (Schneider \& Enste, 2013).

Table 1: Taxonomy of underground economic activities

\begin{tabular}{|l|l|l|l|l|}
\hline Type of activity & \multicolumn{1}{|c|}{ Monetary transactions } & \multicolumn{2}{|c|}{ Non-monetary transactions } \\
\hline Illegal activities & $\begin{array}{l}\text { Trade in stolen goods; drug dealing and } \\
\text { manufacturing; prostitution; gambling; } \\
\text { smuggling; fraud; human trafficking, drug } \\
\text { trafficking and weapon trafficking. }\end{array}$ & $\begin{array}{l}\text { Barter of drugs, stolen goods, smuggling, } \\
\text { etc.; producing or growing drugs for own } \\
\text { use; theft. }\end{array}$ \\
\hline Legal activities & $\begin{array}{l}\text { Tax evasion } \\
\text { Unreported income from } \\
\text { self-employment; wages, } \\
\text { salaries and assets from } \\
\text { unreported work related to } \\
\text { legal services and goods. }\end{array}$ & $\begin{array}{l}\text { Employee } \\
\text { discounts; fringe } \\
\text { benefits. }\end{array}$ & $\begin{array}{l}\text { Barter of legal } \\
\text { services and goods. }\end{array}$ & $\begin{array}{l}\text { All do-it-yourself } \\
\text { work and neighbour } \\
\text { help. }\end{array}$ \\
\hline
\end{tabular}

Source: Mirus \& Smith (1997), with additional remarks from Schneider \& Enste (2000)

Economic activity that falls outside the scope of the National Accounting Systems appears in the literature by various terms such as shadow, informal, unreported, hidden, black, underground, grey, unrecorded, clandestine, offshore, parallel or subterranean economy. Tanzi (1982 as cited by Eilat \& Zinnes, 2000) describes shadow activity as the tendency of people and firms to perform their economic activities without the intervention or cooperation of the state. These include activities that:

1) Evade taxes (either as part of general fiscal collections or as specific service charges);

2) Ignore currency requirements (e.g. local currency as the only legal tender);

3) Avoid regulatory requirements (e.g. licensing);

4) Fail to appear in statistical reporting mechanism; and

5) Are per se illegal (e.g. drug dealing).

\section{Driving Forces of the Shadow Economy}

To understand its complex economic and social impacts, it is important to understand what cause the appearance of the shadow economy, in general. Dreher et al. (2005) distinguish two main groups of driving forces of the shadow economy: 1) high tax and social security burdens as principal causes, and 2) decrease in institutional quality indicated by increased bureaucracy, regulatory discretion, rule of law, corruption and a weak legal system. Schneider et al. (2011) have modified the previous list and focus on four main groups of driving forces such as: 1) tax and social security contribution burdens, 2) increased intensity of regulations (e.g. labour market regulations, trade barriers etc.), 3) deterioration of the quality of public goods and services, and 
4) the state of the 'official' economy (booming or in a recession). In other words, people are motivated to be engaged in shadow economy if: (a) they can save significant amount of money by working outside of the official economy, (b) working in shadow economy is commonly accepted by the community (mainly in undeveloped and developing countries), (c) there is a low risk of getting caught in some shadow economic activity (especially in remote and rural areas), and (d) payments for goods and services are made in cash (e.g. in tourism-related businesses). The vast majority of empirical studies in this field of research have confirmed that the increase of the tax and social security burden is, among other, the most influential trigger of the growth of shadow economy (see Table 2).

Table 2: Main causes of the Increase of the Shadow Economy

\begin{tabular}{|l|c|c|}
\hline \multicolumn{1}{|c|}{ Factors influencing the shadow economy } & Influence on the shadow economy (in \%) \\
\cline { 2 - 3 } & (a) & (b) \\
\hline (1) Increase of the Tax and Social Security Contribution Burdens & $35-38$ & $45-52$ \\
\hline (2) Quality of State Institutions & $10-12$ & $12-17$ \\
\hline (3) Transfers & $5-7$ & $7-9$ \\
\hline (4) Specific Labour Market Regulations & $7-9$ & $7-9$ \\
\hline (5) Public Sector Services & $5-7$ & $7-9$ \\
\hline (6) Tax Morale & $22-25$ & $78-96$ \\
\hline Influence of all Factors & $84-98$ & \\
\hline $\begin{array}{l}\text { a) Average values of 12 studies. } \\
\text { b) Average values of empirical results of 22 studies. }\end{array}$ & & \\
\hline
\end{tabular}

Source: Schneider (2009)

The previous group of causes that encourage the growth of shadow economy can be expanded with findings provided by Bejaković who added several other factors such as: the lack of democratic, economic and regulative institutions, absence of experience of paying taxes, discretionary rights of public servants, and government profligacy (Ott, 2002). Beside the national (internal) economic and social factors influencing the size and impacts of the shadow economy, Katsios (2006) pointed out that these issues are magnified with the explosion of international free trade and economic integrations throughout the world, which call for international harmonisation and the introduction of strategic global law enforcement policies to combat them.

\section{Methods for Estimating the Size of the Shadow Economy}

Estimates of the size of the shadow economy vary widely across countries, partly because underground economic activity is, by its nature, difficult to observe, and partly because of divergent points on the definition of the shadow economy (Viksne \& Mazure, 2011). To discuss possible alternatives in measuring the size and devel- 
opment of the shadow economy in some country, Schneider \& Enste (2013) suggest three main groups of methods:

a) Direct approaches - microeconomic approaches like employing surveys based on voluntary replies, or tax auditing (determining discrepancy between income declared for tax purposes and actual earnings);

b) Indirect approaches - or 'indicator' approaches, are mostly macroeconomic such as: 1) discrepancy between national expenditure and income statistics, 2) discrepancy between the official and actual labour force, 3) monetary methods, like transaction or cash demand approach, and 4) physical input method, like electricity consumption;

c) The model approach - considers multiple indicators and multiple causes (MIMIC) that lead to the existence and growth of the shadow economy, and to its multiple effects over time.

\section{The Impacts of the Shadow Economy}

In order to attribute the impacts of the shadow economy on the overall economic performance and social structures as positive or negative, authors generally agree that the shadow economy is predominantly negative and undesirable occurrence that needs to be kept within certain bands in order to prevent negative long-term consequences. In its negative aspects, shadow economy reduces government revenues and distorts official indicators (growth, unemployment, income distribution, etc.), thereby influencing public sector decisions, producing changes in individual incentives and remuneration factors, etc. (Dell'Anno et al., 2006). In that context, Bejaković (2015) emphasizes that the reduced public revenues from taxes, in turn, reduce the quality and quantity of publicly provided goods and services. This can lead to an increase in the tax rates for firms and individuals in the official sector, quite often combined with deterioration in the quality of public goods and of the administration, leading to an even stronger incentive for individuals and companies to participate in the shadow economy. From a microeconomic perspective, the shadow economy tends to distort fair competition among firms, to inhibit the creation of regular employment and to cause productive inefficiencies (Berrittella, 2015). The shadow economy has a tendency to increase in its size and impacts during the time of economic slowdown (Viksne \& Mazure, 2011), when more people try to compensate their losses of income from the official economy through additional shadow economy activities (Schneider, 2016). It could be also added, as Georgiu's (2013) panel data analysis revealed, that shadow economy tends to push up house prices and distorting real estate markets.

Nevertheless, Fleming et al. (2000) pointed out that not all shadow economic activity should be labelled negative and therefore discouraged. Even the early works on shadow economy identified that informal sector contribute to the creation of markets, 
increase financial resources, and enhance entrepreneurship (Asea, 1996). Additionally, an active shadow economy might imply the presence of inefficient economic policies (De Soto, 1989), can help the transition towards market economies (Štulhofer, 1999; Glinkina, 1999), and stimulate the official economy, as at least two-thirds of the income earned in the shadow economy is immediately spent in the official economy (Schneider, 2008).

\section{The Size of the Shadow Economy}

During the last two decades a considerable work has been devoted to estimating the size of the shadow economy in countries around the world, using a variety of methods. Unfortunately, all of these methods are, to some degree, imperfect, and different methods appear to generate divergent estimates (Fleming et al., 2000).

According to Schneider \& Enste (2013), there are strong indications of a growth of the shadow economy on a global scale. The size, the causes, and the consequences vary in each country. In their valuable comparative analysis, Schneider et al. (2011) revealed that the shadow economy has reached remarkable proportions, with a weighted average value of $17.2 \%$ of official GDP over 162 countries between 1999 and 2006/2007. More in depth analysis showed that the size of shadow economy ranges from $8.5 \%$ to $30 \%$ of the GDP in 25 OECD countries (represented by Switzerland, country with the lowest share of shadow economy in its GDP in the world), from $18.1 \%$ to $65.8 \%$ of the GDP in 21 transition countries (with Slovak Republic at the top of the list), and finally from $12.8 \%$ to $66.6 \%$ in 98 developing countries of the world (among which China was the least affected by shadow economy). These figures clearly indicate that shadow economy is present in all types of economies, regardless of the degree of economic development and the political system of the country.

More recent study on shadow economy in Europe revealed that, in 2013, the total value of economic activities in Europe that fell outside the reach of government authorities was $€ 2.15$ trillion, of which roughly $2 / 3$ was from undeclared work and $1 / 3$ comes from underreporting (from the businesses that deal heavily in cash, such as, shops, bars and taxis, reporting only part of the income to avoid tax burden). The same study showed that the size of shadow economy in Europe was as large as 18.5\% of the official economy (Visa Europe et al., 2013). So far, the newest calculations on the size and development patterns of the shadow economy in Europe, for 2015, reveals that: (1) a further decline of the shadow economy is present in 25 out of the 36 OECD countries due to the recovery of the official economy; (2) the eastern or central European countries and/or the "new" European Union member states have higher shadow economies than the "old" European Union countries. Hence, it is noticeable that there is an increase of the size of the shadow economy when analysing data across countries from west to east; and (3) there is an increase in the size and de- 
velopment of the shadow economy across countries from north to south. On average, the southern European countries have considerably higher shadow economies than those of Central and Western Europe (Schneider, 2015).

\section{The Shadow Economy in Tourism: Literature Review}

According to the Google Scholar database, there are only several narrowly focused empirical studies on the shadow economy in tourism (e.g. Wahnschafft, 1982; Skalpe, 2007; Slocum et al., 2011, Din et al., 2016; Šergo, et al., 2017) and very few attempts to develop efficient methodology to measure its size and impacts (e.g. Ivandić \& Radnić, 1997; Stučka, 2002; Badariah et al., 2015), which leads to conclusion that the shadow economy in tourism is still pretty under-researched area. In spite of the size of the global tourism economy in terms of tourist arrivals, expenditure, exports and employment, as well as the fact that many governments heavily rely on tourism as a source of benefits, it is surprising that, so far, little attention has been paid to deeper understanding, decomposition and measurement of tourism-related shadow economy across countries. Presumably, there are three main reasons why shadow economy in tourism has received such scarce scientific attention: 1) highly fragmented and complex tourism business structure significantly expands the scope of the research; 2) spatial dispersion of tourism-related business entities and activities makes research difficult to operationalize; and 3) the social sensitivity of the topic, particularly when it comes to underdeveloped and remote tourism receiving areas.

Although there is plenty of real-life evidence that tourism-related shadow economy is ubiquitous and shows up across various economic activities and in all types of tourism destinations, the available empirical studies in this field are mainly concentrated around two key aspects: 1) identifying tourism-related economic activities that are deeply affected by the shadow economy, and 2) measuring the size of unregistered workforce in tourism.

One of the earliest contributions in this field is the article provided by Wahnschafft (1982), in which author has investigated the dichotomy of formal and informal sectors and its implications on tourism in Thailand. Two decades later, an interesting study on hidden economy in tourism was conducted by Skalpe (2007), who identified that there has been more research of the shadow economy at the national level than at the industry level. The same author used analytical framework developed by Schneider (2002) assuming that macro based framework can be translated to the industry level. In such manner, Skalpe found out that hotels and restaurants in Norway use two different cash registers (official and unofficial), keep extra income from hosting special events away from tax officials, and support the trade of illegal alcoholic drinks. In that context, he argued that the shadow economy in this sector can be regarded as deteriorating to all parties involved: the customers, the employees, the companies, 
the government, and the policymakers. For Danish restaurant sector, Hjalager (2008) was assessing the economic importance and consequences of tax fiddles, employment of illegal/undeclared labour, and illegal import of supplies. Having in mind that the tax rates and wages in Denmark are among the highest in Europe, it is not surprising that such economic environment increases temptation of entrepreneurs to enter the informal economy.

In 2011, Slocum et al. (2011) have conducted a research on aspects of informal economy in Tanzanian tourism, which was observed as a means to alleviate poverty and generate some net benefits to the poorest and thus the most vulnerable groups of residents. The role of shadow economy in e-business adoption of tourism-related SMEs in Bulgaria was investigated by Vladimirov (2015), who found out that the spread up of shadow economy is more likely to work against the e-business adoption by small tourism firms.

As cited by Badariah et al. (2015), the negative impact of the shadow economy on tourism in Montenegro has been reported by Pavičević (2014), who pointed out that the development of the Montenegrin tourism has been halted as a result of the uncontrolled activities in the shadow economy, such as the unrestrained increase in number of unregistered private accommodation facilities in coastal region which compromises the quality of tourism destination and destroys the development of the basic tourism-related industries. Similar observations on tourism-related shadow economy in Montenegro were provided by Milić (2014) who stated that the largest problems of shadow economy in tourism-related economic activities are unreported seasonal accommodation capacities and related income, absence of cash registers in catering facilities, non-invoicing, unregistered workers, failure in tourist taxes collection, etc.

In their cross-country analysis, Din et al. (2016) examined the short-run and longrun relationships between international tourism receipts and shadow economy for 149 countries over the period 1995-2008, and came to the same conclusion as Pavičević (2014) did, that the long-run existence of the shadow economy adversely affects the tourism system.

According to Zhang (2017), the shadow economy in tourism is a growing phenomenon in both developing and developed countries, emphasizing informal employment as its main pillar, since the formal economy does not create enough formal jobs for all jobseekers. In his study Zhang also highlighted the fact that both informal enterprises and workforce in tourism need to be valued for their contributions and integrated into economic planning and legal frameworks. As stated by Chen (2012), this leads to the new economic paradigm: a model of a hybrid economy that embraces the traditional and the modern, the small scale and the large scale, the informal and the formal.

Unfortunately, none of the above cited authors have actually assessed the real size of the shadow economy in tourism, but rather highlighted its partial implications on 
local, regional or national economic environment. Among all these and other studies on shadow economy in tourism, the main limitations lie in the scarcity of empirical evidence, modest literature and data in this field of research, and therefore, need to be complemented with new insights and considerations.

\section{Evidences of Tourism-Related Shadow Economy in Croatia}

\section{Early Attempts of Quantifying the Value of Shadow Economy in Croatia}

Since Croatia's independence in 1990, there were several attempts to calculate the value of the shadow economy using different approaches and data sets. The first observations in this field of research were done by Bejaković in his early works on measuring the unofficial economy in Croatia using macroeconomic approach (1994; 1997), followed by contribution of Crnković-Pozaić (1997) who employed a labour survey approach, and Jankov (1997) who used a monetary approach to estimate the size of shadow economy in Croatia. These and several other contributions were important components of the national project on 'The underground economy in Croatia' conducted by the Croatian Institute of Public Finance in 1996 (Ott, 1997). An introduction of new study approaches and several methodological changes were adopted in second project, in 2001, which have included 'national accounts', 'monetary methods', 'labour force surveys', and 'tax evasion' approaches (Ott, 2002).

For the purpose of the second project, the group of authors, gathered around the same Institute, have attempted to evaluate the size of shadow economy in Croatia from 1990 until 2000 in several individual industries, e.g. in agriculture, industry and trade, tourism, and foreign trade. Among the authors who attempted to estimate the size of the overall shadow economy in Croatia it is valuable to point out contributions provided by Lovrinčević et al. (2002) who used the Eurostat approach adapted for transition countries, and Madžarević-Šujster \& Mikulić (2002) who used the National Accounting System. Various evaluation methods used in this project gave different results. National accounting discrepancy method (discrepancy between income and expenditures) shows a growth of the shadow economy from 1990 to a maximum of $37 \%$ of GDP in 1993 and a steady reduction to $7 \%$ of GDP in 2000. In accordance with that method used for 1990-1995 time period, the shadow economy came on average to about 25\%, and in 1996-2000 to an average of 10\% of GDP. The Eurostat method and estimates of tax evasion coincide with these trends, while two monetary methods and the consumption of electrical energy method show a rise in the shadow economy in 1995-1999 period with trends at annual levels of between $22 \%$ and $34 \%$ and a fall in 2000 (Ott, 2002). Since then several authors have made their contributions to the field, like Lovrinčević et al. (2006), Švec (2009), Lovrinčević et al. (2011), Kurnoga Živadinović \& Groznica (2012), and Bejaković (2015), all with modest im- 
provements in creating reliable monitoring system that would ensure methodologically consistent long-run dynamic analyses and estimations of the shadow economy.

Apart from domestic efforts, to illustrate dynamics in size of the shadow economy in Croatia as a percentage of the official GDP, findings of two comprehensive studies, provided by Schneider et al. (2011) and Schneider (2015), have been merged (see Figure 1).

Figure 1: Size of the shadow economy in Croatia as a percentage of GDP, 1999-2015

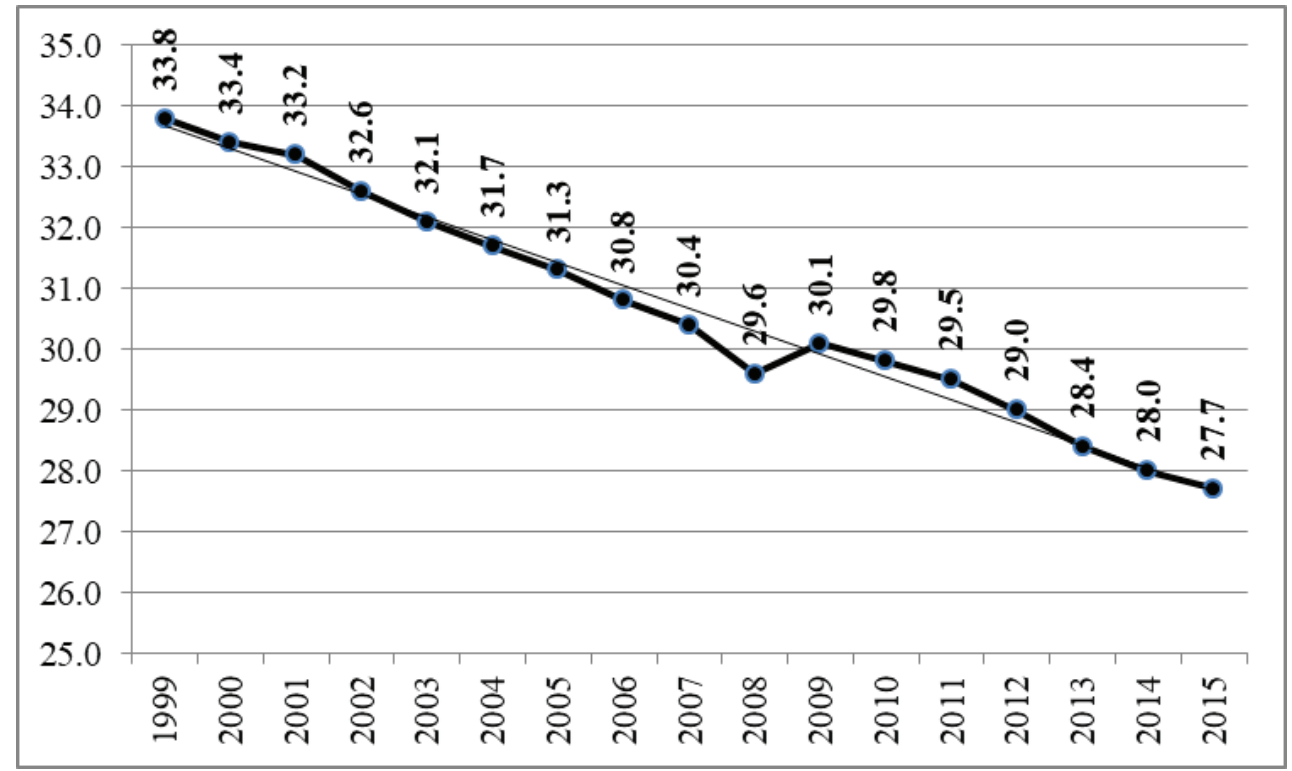

Source: Schneider et al. (2011) for data series 1999-2007, and Schneider (2015) for data series 2008-2015

A data series shown in Figure 1 reveals that the size of shadow economy in Croatia is constantly decreasing from $33.8 \%$ in 1999 down to $27.7 \%$ in 2015 . The lowest size of the shadow economy ever and its constantly decreasing trend are certainly positive outcomes towards more efficient public services and revenue distribution, but still there is a lot of scope for improvement. As seen in Figure 2, Croatia belongs to the group of countries with the largest size of the shadow economy comparing to the officially recorded economic activity. 
Figure 2: Size of the shadow economy of 31 European countries in 2015 (in \% of official GDP)

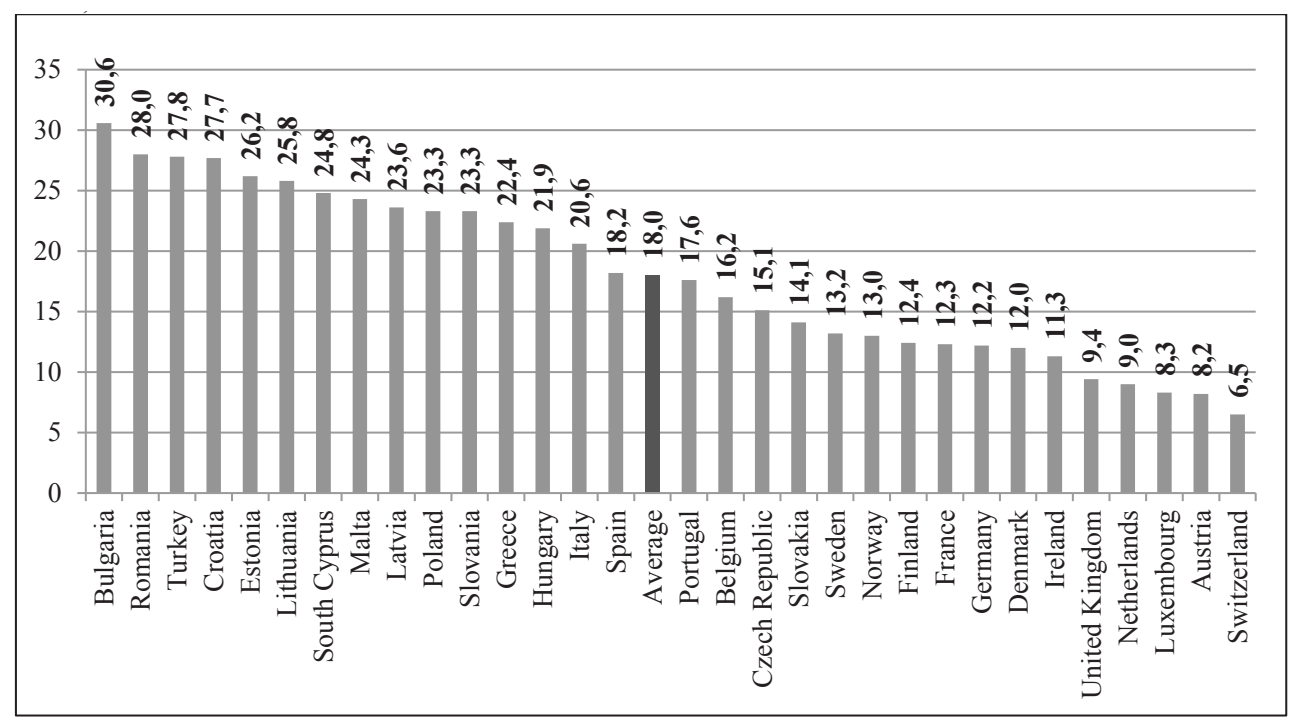

Source: Schneider (2015)

Among 31 analysed countries in Europe, in 2015, Croatia took fourth position behind Turkey, Romania and Bulgaria, which makes Croatia a country highly affected by the shadow economy. Although there are many independent and overlapping causes of such a high rank, in case of Croatia tourism could play a key role in encouraging shadow economy. Such statement is supported by findings published in the report on shadow economy in Europe in 2013 where wholesale and retail, hotels and restaurants, as well as transportation and communications were economic activities with highest shares of informal economy (Visa Europe et al., 2013).

\section{Incidence of the Shadow Economy in Tourism in Croatia and Related Studies}

Shadow economy in tourism represents, at the same time, a problem and a challenge that affects not only the service providers and tourists, who wish to make or save more money, but also the host communities, public sector, tourism-related businesses, and labour market. Owing to its diverse and highly fragmented economic structure, tourism is able to support and integrate a number of activities that go under the umbrella of shadow economy. This primarily refers to hotel and restaurant business operations, but also includes transportation, tourist attractions and retail businesses, sport facilities and equipment, events, excursions, charter boat operations and many other tourism-related economic activities. For these and other reasons, the main pur- 
pose of this chapter is to explain the key factors that are accountable for the incidence of the shadow economy in tourism in Croatia, and to highlight the most valuable scientific attempts in Croatia related to this field of research.

Given that Croatia is a small, open economy that heavily relies on tourism as a major source of economic growth and development, the issues related to active shadow economy should be clearly addressed and carefully analysed. There are five main reasons why tourism can be considered as 'the main suspect' responsible for the migration of economic activities from the official to the shadow economy:

a) Tourism, as predominantly service providing set of activities, heavily depends on labour force participation (including the undeclared work), which is difficult to trace and register;

b) Tourism is often developed in rural settings (e.g. farms or hunting grounds), mountain regions (e.g. adventure cycling routes) and remote areas (e.g. small islands or lakes) whose tourism-related activities are rarely thoroughly detected by tax authorities;

c) Tourism's highly fragmented economic structure consists of many service-providing and production entities, mainly SMEs (e.g. handicraft producers) and individuals (e.g. family accommodation service provider), and a chance for such small-scale businesses to be constantly checked by tax authorities is rather low;

d) $\mathrm{C} 2 \mathrm{~B}$ transactions in tourism are in the most cases of small amounts (e.g. taxi ride) and done in cash (including tips), without issuing an invoice for a product (e.g. bottled water) or service (e.g. car wash);

e) A large fluctuation of customers (e.g. short stay in a motel), supported by high seasonality (e.g. during the summer), makes work difficult for tourist and/or tax inspectors.

To our best knowledge, only a few authors have attempted to estimate the size of shadow economy in tourism in Croatia, so far. Primarily it is because of the previously mentioned reasons, but also because of the complex economic structure of tourism that significantly limits the ability of conventional approaches in estimating the size and impacts of shadow economy. The first pioneer study in this field was provided by Ivandić \& Radnić (1997) who actually limited the scope of their study to the estimation of shadow economy only in hotels and restaurants, while the rest of tourism-driven economy in Croatia remained unanalysed. They also found out that the number of tourist overnights in camp sites was $20 \%$ higher than official statistics has recorded, while unregistered number of tourist overnights in family accommodation was $30 \%$ of the registered figures for 1994. Based on such assumptions, they calculated that $12.6 \%$ of total nights spent in Croatia that year remained unregistered. The unofficial economy in hotels and restaurants is derived from surveys of expenditures by tourists and the local population. Since the registered income was $22 \%$ smaller than the estimated income in this sector, Radnić \& Ivandić concluded that the unofficial economy in tourism and the hotel and catering industry was $22 \%$ (Bićanić \& Ott, 1997). 
In order to provide more in-depth analysis of the shadow economy, Stučka (2002) tried to estimate its size and value also in other tourism-related businesses by using various data and approaches. In his research, Stučka analysed the difference between incoming tourism demand registered by the international survey on foreign tourist movements to Croatia and officially registered demand in Croatia. In this context, the share of unregistered international tourist arrivals in 1998 was estimated to be between $18.6 \%$ and $28.8 \%$. Besides this, he also used approach based on the oscillations in consumption of water and electricity during the year, and tried to estimate the value of cash and cheques exchanged by foreign tourists for local currency in financial institutions in Croatia. In Ott's (2002) reference on the Stučka's study, it is clearly stated that such approach offers only the basic insight into the area, while future studies need to be complemented with additional microeconomic knowledge and more reliable set of data.

Using the Eurostat methodology, Lovrinčević et al. (2006) have estimated the total value of the shadow economy in Croatia to be slightly more than HRK20 billion ( $€ 2.7$ billion) or $11.2 \%$ of the official GDP, using 2002 data. The total value of the shadow economy in hotels and restaurants was estimated to HRK1.8 billion (€240 million or $8.8 \%$ of total shadow economy in Croatia), in 2002, while the size of the shadow activities within this economic activity solely was estimated to be $33.7 \%$, the highest among all economic activities. Apart from the hotels and restaurants, the size of the shadow economy of all other tourism-related economic activities remained embedded in total values of these economic activities, which implies that the size of the shadow economy in tourism was significantly higher than estimated $8.8 \%$ of the GDP, in 2002.

Another interesting approach in estimating the size of shadow economy in tourism in Croatia was applied by Vukšić (2009), who has analysed dynamics of quarterly published data in the balance of payments related to international tourism receipts (export of services) and net errors and omissions (NEO) during the 1999-2007 period. The findings imply a very large amount of unrecorded seasonal accumulation of foreign cash from foreign tourist spending during the third quarters, which have reached over US $\$ 2.4$ billion in some of the analysed years. The author concluded that it seems likely that this accumulation is largely related to shadow economy in tourism.

The latest study on this matter was conducted by Šergo et al. (2017), in which authors used panel data vector autoregressive (VAR) model and generalized method of moments (GMM) to examine the association between shadow economy share in GDP and international tourism receipts share in total exports, for 30 European countries. They came to the conclusion that European countries would be successful in raising official economy growth through better controlling of tourism receipts flow. Unfortunately, the purpose of this study was neither to conceptually clarify the shadow economy's components nor to improve the methodology that would enable tax authorities more efficient monitoring of the shadow economy in tourism. 


\section{Further Considerations on Monitoring the Shadow Economy in Tourism}

As previously elaborated, there are several approaches and related methods to estimate the size of the shadow economy; however, each of them has its own strengths and weaknesses. This is because the variables that affect the phenomenon are difficult to trace and to validate empirically. Therefore, the shadow economy cannot be measured precisely, but only estimated using input data that could differ much from one country or economic activity to another.

For better understanding and more accurate measuring of the shadow economy in tourism (in Croatia or elsewhere), some further considerations that support the development of methodology in this regard are provided. These considerations are based on the progress achieved in conceptualization of tourism-related shadow economy matrix, some simple calculations and reasonable assumptions.

The first consideration is directed to lodging service providing in private houses, apartments and rooms, which is, by far, the most frequent activity of shadow economy in tourism. Given that, in 2016, almost 58\% of all commercial-based tourist accommodation facilities in Croatia were in privately owned housing units, a large proportion of the shadow economic activities in the lodging industry seem to be directly related to this spatially dispersed and highly fragmented supply structure. During the 2000-2016 period there has been a substantial growth of capacities in privately owned rooms, apartments and houses $(+144 \%$, measured by number of beds), followed by camp-sites $(+20 \%)$ and hotels $(+9.2 \%)$, indicating a high discrepancy between them (CBS, 2017c). According to the official data source, the reason for suspecting in deeply-rooted shadow economy in tourist accommodation service-providing lies in fact that the annual occupancy was only $8.3 \%$ in 2000 and $14.6 \%$ in 2016. From a business efficiency point of view, such low occupancy rate rules out the possibility of running profitable lodging business operations. Thus, it can be concluded that much of the economic activity related to the service-providing in these facilities, and consequently in the entire lodging industry in Croatia, can be regarded as being informal.

The second consideration is related to 2011 Census data (CBS, 2013) on the quantity of housing units (flats and private apartments) in the coastal region of Croatia, which are temporary uninhabited or abandoned (160,000 units), or being occasionally used (185,000 units) or used for businesses other than tourism-related (9,000 units). Therefore, it is assumed that the significant proportion of these more than 350,000 units is offered to tourists without registration or reporting to the authorities. This is particularly true if we know that more than $90 \%$ of these premises, according to the CBS (2013), are located in seaside destinations.

The third consideration is directed to the expansion of various special interest tourism products, like outdoor adventure or ecotourism activities, food \& wine tours, safari or bird watching, etc., whose supply is not concentrated in renowned tourism 
destinations, but rather dispersed in rural areas. These areas and business operations (including transactions) are often too costly for tax authorities and/or tourism inspection to check for irregularities and underreporting. Nevertheless, services and products sold to tourists in this manner give chance for local communities in remote and low-income areas to survive, stay and prosper in today's increasingly competitive and globalized tourism market. The net effect of such unregistered foreign cash accumulation will sooner or later appear in balance of payments due to currency exchange or spent on imported goods (e.g. cars, boats, electronic devices, special equipment etc.).

The fourth consideration is focused on items related to balance of payments. As concluded by Vukšić (2009), NEO is a residual or balancing item in balance of payments that refers to amount of unrecorded accumulation of foreign cash from international tourist expenditure. Given that macroeconomic aggregates in Croatia have a strong seasonal component influenced by international tourism demand with its peak in a third quarter, it seems interesting to continue the observations on NEO trends (Figure 3).

Figure 3: International tourism receipts and Net errors and omissions in third quarters in Croatia, 2000-2016 (in US\$ billion)

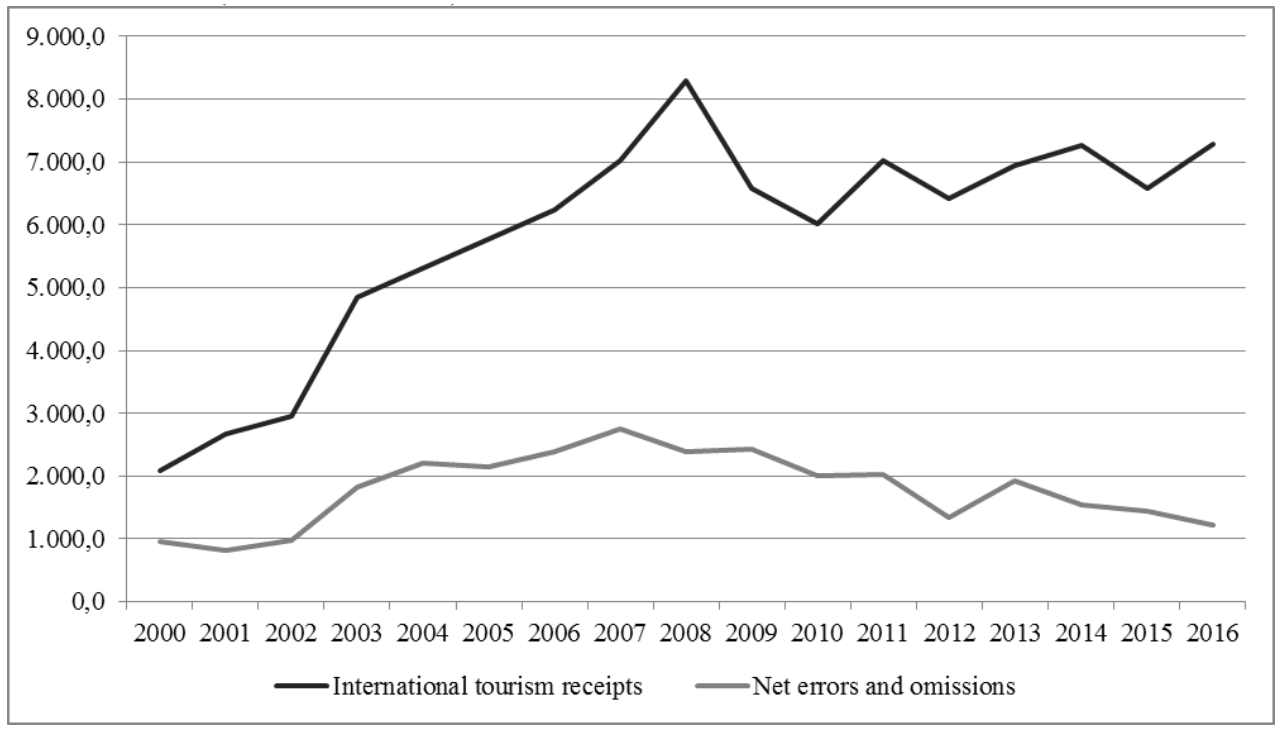

Source: CNB (2017)

In time period between 2000 and 2016, the correlation between international tourism receipts and NEO is about $r=0.6298$, which indicates that there is a moderate positive relationship between these two variables. The share of NEO in international tourism receipts in observed time period varies between $45.4 \%$ in 2000 and $16.6 \%$ in 2016, with constantly decreasing trend. 
Further considerations should go into more precise selection of determinants that are commonly associated with the shadow economy in tourism. These determinants refer to economic activities in tourism that are difficult to trace and control by tax authorities, such as taxi services, boat excursions, bus sightseeing tours, unofficial tour guiding, sports equipment rental (e.g. bicycles), outdoor events, food stalls, open-air markets with food and traditional handicrafts, souvenir shops, and many other activities with large cash inflow from temporary visitors.

\section{Policy Recommendations}

Although there are many aspects, causes and national peculiarities that shape the sizes and patterns of the shadow economy growth across countries, several common recommendations, considered 'as golden rules', have emerged from previous empirical studies that might help governments to reduce the adverse impacts of shadow economy. According to Schneider et al. (2011), reducing the tax burden is the best policy measure to reduce the shadow economy, followed by lessening of fiscal and business regulations. In that sense, Schneider has also pointed out that more emphasis should be put on improving enforcement of laws and regulations, rather than increasing their number. However, some governments prefer to introduce more regulations and laws, when trying to reduce the shadow economy, mostly because it leads to an increase in the power of the bureaucrats and to a higher rate of employment in the public sector (Schneider, 2008). In addition, the increase in tax morale (Torgler \& Schneider, 2007) and better institutional quality (Dreher \& Schneider, 2010) are also important prerequisites for lowering the size of shadow economy.

The most recommendations that arose from the second project on underground economy in Croatia, completed in 2002, are also applicable to present times, because there is still a lot of work to be done in order to keep public finances in balance from one side, and to relieve the tax burden on labour and entrepreneurs, from the other side. A selection of those recommendations aiming at lowering the size of shadow economy in tourism is summarized as follows (according to Ott, 2002):

- keep tax and regulatory burden as low as possible and penalise tax evasion;

- avoid tax-breaks for individual economic activities, regions and occupations;

- suppress the economic reasons for the existence of the shadow economy;

- build up ethical norms and encourage the culture of paying taxes;

- reduce inequalities in the society and reasons for working in the shadow economy;

- strengthen legal system and institutional mechanisms for carrying out the laws;

- improve the efficiency of the public administration and tax authorities;

- provide a flexible labour market and expand educational opportunities; 
- carry out systematic scientific monitoring of the scope, causes and consequences of the shadow economy;

- organise a survey aiming at assessing the size of the shadow economy;

- improve the statistical base and adapt the surveys about consumer spending;

- reduce the statistical reasons for the existence of shadow economy;

- encourage transparency in public tenders and contracts etc.

In order to make these recommendations applicable and effective, authors suggest that government should foremost support the renewal of the mentioned scientific project on shadow economy in Croatia, including special researches and studies (i.e. in tourism), that could be later on transformed into the National strategy for reducing negative impacts of shadow economy. Based on the guidelines stated in the Strategy, a related Action plan should be set up to define priorities, timeframes and duties of all stakeholders involved in its implementation. It would be irrational to expect that all recommendations and guidelines should be enforced immediately, but their gradual implementation and systematic approach in dealing with 'hot topics' could result in larger net inflow of tax revenues, which in turn would bring about more supportive tax system for investors and entrepreneurs, as well as more active public sector's participation in public-private partnerships projects.

\section{Conclusion}

Shadow economy has important social, political and economic functions, but in general it is considered as negative phenomenon for many reasons. Previous studies have shown that in a short-run the shadow economy can act to stimulate economic activities and employment, but over a longer period of time, persistent shadow economy tends to destroy social norms and values, and ultimately leads to an economic slowdown or even a recession.

During the past two decades, the shadow economy has become one of the major concerns for tax authorities, policy makers and academics, since the value of the informal economy has reached a substantial amount across countries. The main reason for such concern arises from the fact that the shadow economy is prone to be resistant to government repressive measures towards suppressing the shadow economy, but highly responsive to economic crises, and impossible to be eradicated. Regardless of the level of economic development, political system or geographical position, every country is facing with challenge of how to quantify, treat and suppress its flourishing informal part of the national economy. In highly developed countries the size of shadow economy is as low as 7-10\% of the official economy, while in some undeveloped or developing country this share can be even up to $70 \%$. If we exclude the ex-Soviet countries, the size of shadow economy in Europe is varying between $7 \%$ and $30 \%$ of the official GDP. 
The latest report on the size of overall shadow economy in Croatia showed that around $27.7 \%$ of the total value of national GDP is still flowing through informal transaction channels, but the good fact is that the share of these activities is in gradual decline. Given that tourism is important driving force of the Croatian economy, the existence of the shadow economy in tourism is considered challenging due to the fact that many businesses, investments, projects and public sector stability heavily depend on the success of tourism. So far, there are several available scientific contributions aimed at decomposition of tourism-related shadow economy structure and measurement of its impacts on national economy, but still there is plenty of scope for further development of the concept and the methodology.

In order to support better understanding of the shadow economy in tourism, the present study tended to emphasize some additional aspects and determinants of the shadow economy in tourism in Croatia, which may serve as guidelines for further research efforts in this field. In order to reduce its size and negative impacts on the economy and society, policy makers are provided with several recommendations related to tax and institutional system reforms in order to mitigate negative impacts of shadow economy on the official economy. Given that the scarcity of empirical evidence, modest body of literature and limited data, represent the key limitations of all individual researches in the field of shadow economy, some new projects, clarifications, and experts' considerations are necessary to elucidate its scope, structure and implications.

\section{REFERENCES}

Asea, P.K. (1996). The Informal Sector: Baby or Bath Water? Carnegie-Rochester Conference Series on Public Policy, 45, 163-171. DOI: 10.1016/S0167-2231(96)00022-X

Badariah, H.D., Habibullah, M.S. \& Baharom, A.H. (2015). Does the Shadow Economy Matter for Tourism? International Evidence. Taylor's Business Review, 5(1), 1-9. URL: http://www.taylors.edu.my/tbr/uploaded/2015_vol5_issue1_p1.pdf

Bajada, C. (1999). Estimates of the underground economy in Australia. Economic Record, 75(4), 369384. DOI: $10.1111 / j .1475-4932.1999 . t b 02573 . x$

Bejaković, P. (2015), A revision of the shadow economy in Croatia: causes and effects. Economic Research, 28(1), 422-440 DOI: 10.1080/1331677X.2015.1059104

Berrittella, M. (2015). The Effect of Public Education Expenditure on Shadow Economy: A Cross-Country Analysis. International Economic Journal, 29(4), 527-546. DOI: 10.1080/10168737.2015.1081259

Bićanić, I. \& Ott, K. (1997). The unofficial economy in Croatia: Causes, size and consequences. Occasional paper No. 3. Zagreb: Institute of Public Finance.

Caridi, P. \& Passerini, P. (2001.). The underground economy, the demand for currency approach and the analysis of discrepancies: Some recent European experience. Review of Income and Wealth, 47(2), 239-250. DOI: 10.1111/1475-4991.00014

CBS. (2017a). Tourism in 2016. Statistical Reports No. 1594. Zagreb: Croatian Bureau of Statistics.

CBS. (2017b). Tourist Arrivals and Nights in 2016. First Release, Year: LIII, No. 4.3.2. Zagreb: Croatian Bureau of Statistics. 
CBS. (2017c). Non-Profit Tourism Activity in 2016. First Release, Year: LIII, No. 4.3.3. Zagreb: Croatian Bureau of Statistics.

CBS. (2013). Census of Population, Households and Dwellings 2011. Statistical Reports, No. 1469. Zagreb: Croatian Bureau of Statistics.

Chen, M. (2006). Linking the formal and informal economy. Oxford, London: Oxford University Press.

CNB. (2017). Bulletin, No. 223, Year XXIII, Zagreb: Croatian National Bank.

Crnković-Pozaić, S. (1997). The unofficial economy measured by labour force data (in Croatian). Financijska praksa, 21(1/2), 169-194.

De Soto, H. (1989), The Other Path: The Invisible Revolution in the Third World. London: I.B. Tauris.

Dell'Anno, R., Gómez-Antonio, M. \& Pardo, A. (2006). The shadow economy in three Mediterranean countries: France, Spain and Greece. A MIMIC approach. Empirical Economics, 33(1), 5184. DOI 10.1007/s00181-006-0084-3

Din, B.H., Habibullah, M.S., Baharom, A.H. \& Saari, M.D. (2016). Are Shadow Economy and Tourism Related? International Evidence. Procedia Economics and Finance, 35, 173-178. URL: https://doi.org/10.1016/S2212-5671(16)00022-8

Dreher, A., Kotsogiannis, C. \& McCorriston, S. (2005). How do institutions affect corruption and the shadow economy? International Tax and Public Finance, 16(6), 773. DOI: 10.1007/s10797008-9089-5

Dreher, A. \& Schneider, F. (2010). Corruption and the shadow economy: an empirical analysis. Public Choice, 144(1), 215-238. DOI: 10.1007/s11127-009-9513-0

Eilat, Y. \& Zinnes, C. (2000). The Evolution of the Shadow Economy in Transition Countries: Consequences for Economic Growth and Donor Assistance. CAER II Discussion Paper No. 83. Cambridge: Harvard Institute for International Development. URL: http://pdf.usaid.gov/ pdf_docs/PNACK691.pdf

Eurostat (2017). Tourism intensity in 2015. URL: http://ec.europa.eu/eurostat/statistics-explained/index.php/File:Tourism_intensity,_2015_(nights_spent_by_residents_and_non-residents_at_ tourist_accommodation_establishments_per_inhabitant)_V2.png

Feige, E. L. (1990). Defining and estimating underground and informal economies: The new institutional economics approach. World Development, 18(7), 989-1002. DOI: 10.1016/0305750X(90)90081-8

Fleming, M.H., Roman, J. \& Farrell, G. (2000). The Shadow Economy. Journal of International Affairs, 53(2), 387-409. URL: http://www.jstor.org/stable/24357758

Georgiu, M.N. (2013). Shadow Economy and House Prices: A Panel Data Analysis in EU, USA, Japan. DOI: $10.2139 / \mathrm{ssrn} .2370424$

Glinkina, S. (1999). Russia's Underground Economy During the Transition. In E.L. Feige \& K. Ott (Eds.), Underground Economies in Transition: Unrecorded Activity, Tax Evasion, Corruption and Organized Crime (pp. 43-63). Aldershot: Ashgate.

Hjalager, A.M. (2008). The Illegal Economy in the Restaurant Sector in Denmark. Tourism and Hospitality Research. 8(3), 239-251. URL:

Ivandić, N., Marušić, Z., Šutalo, I. \& Vuglar, J. (2014). Tourism Satellite Account for Croatia in 2011 and the calculation of indirect and total impacts of tourism in Croatia (in Croatian). Zagreb: Ministry of Tourism and Institute for Tourism.

Ivandić, N. \& Radnić, A. (1997), The size of unofficial economy in tourism and hospitality (in Croatian). Financijska praksa, 21 (1/2), 231-240.

Jankov, Lj. (1997). The monetary form of the unofficial economy (in Croatian). Financijska praksa, 21 (1/2), 157-168. URL: http://www.ijf.hr/hr/publikacije/caopisi/12/financijska-teorija-i-praksa/104/vol-21-1997/226

Katsios, S. (2006). The shadow economy and corruption in Greece. South-Eastern Europe Journal of Economics, 4(1), 61-80. URL: http://www.asecu.gr/Seeje/issue06/katsios.pdf 
Kesner-Škreb, M. (1997). The unofficial economy and development (in Croatian). Financijska praksa, 21(1/2), 315-327.

Kurnoga Živadinović, N. \& Groznica, M. (2012). Estimating The Share Of Employees In The Unofficial Economy In Croatia. Economic Review, 63(1-2), 73-86. URL: http://hrcak.srce.hr/78939

Lovrinčević, Z., Mikulić, D. \& Galić Nagyszombaty, A. (2011). Unofficial economy in Croatia and the impact of the economic recession on the unofficial economy. In Z. Reić \& V. Šimić (Eds.), Conference proceedings challenges of Europe: Growth and competitiveness reversing the trends (pp. 479-908). Split: University of Split, Faculty of Economics.

Lovrinčević, Ž., Marić, Z. \& Mikulić, D. (2006), Maastricht Criteria and the Inclusion of the Underground Economy - the Case of Croatia (in Croatian). Privredna kretanja i ekonomska politika, 16(106), 30-65. URL: http://hrcak.srce.hr/file/28742

Lovrinčević, Ž., Mikulić, D. \& Nikšić-Paulić, B. (2002). Estimate of the Underground Economy in Croatia in the Period 1998-1999 According to the Eurostat Methodology (in Croatian). Economic Trends and Economic Policy, 11(89), 76-121. URL: http://hrcak.srce.hr/file/29179

Madžarević-Šujster, S. \& Mikulić, D. (2002). An Estimate of the Underground Economy Via the National Accounting System (in Croatian). Financijska teorija i praksa, 26(1), 31-56. URL: http://www.ijf.hr/FTP/2002/1/madzarevic-sujster\&mikulic.pdf

Milić, M. (2014). Phenomenon of Grey Economy and its Forms in the Montenegro Economy (in Croatian), Business Excellence, 8(1), 65-80. URL: http://hrcak.srce.hr/123570

Mirus, R. \& Smith, R.S. (1997). Canada's Underground Economy: Measurement and Implications. In O. Lippert \& M. Walker (Eds.), The Underground Economy: Global Evidence of its Size and Impact. Vancouver: Fraser Institute.

Ott, K. (1997). Economic policy and unofficial economy (in Croatian). Financijska praksa, 21(1-2), 2945. Zagreb: Institute of Public Finance.

Ott, K. (2002). The underground economy in Croatia 1990-2000. Occasional Paper No. 12. Zagreb: Institute of Public Finance. URL: http://www.ijf.hr/OPS/12.pdf

Pavičević, R. (2014). Tourism destroys the shadow economy. CG Economist Online. CG Economist online. URL: http://www.cgekonomist.com/?broj=12\&clanak=641\&lang=en

Rimac, K. (2012), Analysis of the structural characteristics and trends in shadow economy in Croatian tourism (in Croatian). Master thesis, Zagreb: Faculty of Economics \& Business.

Schneider, F. (2016). Estimating the size of the shadow economies of 162 countries using the MIMC method. In A. Sauka, F. Schneider \& C.C. Williams (Eds.), Entrepreneurship and the Shadow Economy (pp. 30-59). Cheltenham: Edward Elgar Publishing.

Schneider, F. (2015). Size and Development of the Shadow Economy of 31 European and 5 other OECD Countries from 2003 to 2015: Different Developments. Linz: Johannes Kepler Universität. URL: http://www.econ.jku.at/members/Schneider/files/publications/2015/ ShadEcEurope31.pdf

Schneider, F. (2009). Size and Development of the Shadow Economy in Germany, Austria and Other OECD Countries: Some Preliminary Findings. Revue Economique, 60, 1079-1116.

Schneider, F. (2008). Shadow Economy. In C.K. Rowley \& F. Schneider (Eds.), Readings in Public Choice and Constitutional Political Economy (pp. 511-532), New York: Springer.

Schneider, F., Buehn, A. \& Montenegro, C.E. (2011). Shadow economies all over the world: New estimates for 162 countries from 1999 to 2007. In F. Schneider (Ed.), Handbook on the Shadow Economy (pp. 9-77). Cheltenham: Edward Elgar Publishing.

Schneider, F. \& Enste, D.H. (2013). The Shadow Economy: An International Survey. Cambridge: Cambridge University Press.

Schneider, F. \& Enste, D.H. (2000). Shadow Economies: Size, Causes, and Consequences. Journal of Economic Literature, 38(1), 77-114. URL: http://faculty.nps.edu/relooney/ Schneider.pdf

Skalpe, O. (2007). The Hidden Economy in Tourism (Circumstantial Evidence from the Hotels and Restaurants in Norway). In Chang, P.R. (Ed.). Tourism Management in the 21st Century (337351). New York: Nova Science Publishers. 
Slocum, S.L., Backman, K.F. \& Robinson, K.L. (2011). Tourism Pathways to Prosperity: Perspectives on the Informal Economy in Tanzania. Tourism Analysis, 16, 43-55. URL: https://www.researchgate.net/profile/Susan_Slocum/publication/233652336_Tourism_Pathways_to_Prosperity_Perspectives_On_the_Informal_Economy_in_Tanzania/links/56a1743408ae27f7de266fb5.pdf

Stučka, T. (2002). The Underground Economy in tourism (in Croatian). Financijska teorija i praksa, 26(1), 173-195. URL: http://www.ijf.hr/FTP/2002/1/stucka.pdf

Šergo, Z., Gržinić, J. \& Zanini-Gavranić, T. (2017). Shadow Economy and Tourism Receipts: Evidence from Europe. Interdisciplinary Management Research XIII. Opatija: Faculty of Economics in Osijek, J.J. Strossmayer University of Osijek and Hohchschule Pforzheim University.

Štulhofer, A. (1999). Between Opportunism and Distrust: Socio-Cultural Aspects of the Underground Economy in Croatia. In E.L. Feige \& K. Ott (Eds.), Underground Economies in Transition: Unrecorded Activity, Tax Evasion, Corruption and Organized Crime (pp. 43-63). Aldershot: Ashgate.

Švec, M. (2009). Underground Economy in Croatia (in Croatian). Financijska teorija i praksa, 33(4), 415-444. URL: http://hrcak.srce.hr/48594

Tan, Y.L., Habibullah, M.S. \& Yiew, T.H. (2016). The Shadow Economy in Malaysia: Evidence from an ARDL Model. International Journal of Economics and Management, 10(2), 2161-277. URL: http://econ.upm.edu.my/ijem/vol10no2/(4)-VOL_10(2)2016_Yan-Ling_The\%20Shadow\%20Economy......pdf

Tanzi, V. ed. (1982). The Underground Economy in the United States and Abroad. Lexington: D.C. Heath.

Torgler, B., \& Schneider, F.G. (2007). The impact of tax morale and institutional quality on the shadow economy. CESifo working paper, No. 1899. URL: https://www.econstor.eu/bitstream/10419/25944/1/529371960.PDF

UNWTO. (2017). Tourism Highlights 2017 Edition. Madrid: United Nations World Tourism Organization.

Visa Europe, AT Kearney \& Schneider, F. (2013). The Shadow Economy in Europe, 2013. Linz: Johannes Kepler Universität. URL: http://www.visaeurope.com/en/newsroom/news/ articles/2013/shadow_economy_report. aspx.

Viksne, D. \& Mazure, G. (2011). Shadow Economy and its Relation to the Tax System of Latvia. In Economic Science for Rural Development, 28-29 April 2011 (pp. 219-228). Jelgava, Latvia: Latvia University of Agriculture.

Vladimirov, Z. (2015). Factors for the e-business adoption by small tourism firms and the role of shadow economic practices. European Journal of Tourism Research 10, 5-34. URL: https:// www.google.com/books?hl=hr\&lr=\&id=vkonDwAAQBAJ\&oi=fnd\&pg=PA5\&dq=Factors+for+the+e-business+adoption+by+small+tourism+firms\&ots=C5BkHC36Vi\&sig=gtIJg 5dguEcHJV92poVslgAAQQk

Vukšić, G. (2009). Croatian Balance of Payments: Implications of Net Errors and Omissions for Economic Policy. Newsletter No. 41. Zagreb: Institute of Public Finances.

WTTC. (2017a). Travel \& Tourism: Global Economic Impact \& Issues 2017. London: World Travel \& Tourism Council.

WTTC. (2017b). Travel \& Tourism: Economic Impact 2017 - Croatia. London: World Travel \& Tourism Council.

Zhang, H. (2017). Understanding the Informal Economy in Hospitality and Tourism: A Conceptual Review. Pomona: California State Polytechnic University. 